its time between the discussion of general principles and the lobbying of other interested-or uninterested - parties. The response of the last General Assembly of the United Nations to the request of the Maltese delegation that there should be set up an agency to organize the exploitation of the ocean beds was to establish, on December 20, a sub-committee to study the problem. Advocates of the peaceful uses of ocean sediments are not sure whether this is merely a device for putting off a decision about the formation of an international agency, although it would have been unreasonable to expect that the General Assembly could create an agency which raises all kinds of new problems in international law, and which may be financially hazardous as well, without satisfying itself that there is a feasible task to be accomplished. Nevertheless, there are some, at least, who fear that a committee with more than a score of nations as members will serve as a splendid cloak behind which the nations which fancy their own chances in the exploitation of the sea will be able to block agreement.

At this stage, however, nobody seems inclined to make light of the problems. Strictly academic problems are formidable enough. How, for example, to distinguish between the continental shelf and the deep sea? The committee has apparently given some thought to a measurement of the thickness of the crustal layer as a definition, though some oceanographers would no doubt have interesting reservations to make on that. There are also questions such as whether a treaty which reserved the right of ocean exploration to an international agency should cover the extraction of minerals from seawater as well. But technical problems are insignificant compared with the legal obstacles yet to be fully defined. Freedom of the high seas in the most literal sense is clearly in jeopardy. The question of what to do with any profits from international exploitation is obviously another teaser, although the advocates of an international agency seem at this stage more concerned that there should be profits of some kind than that there should be agreement in advance on the distribution of the profits between peace-keeping, aid for development and other good causes. The committee has a good point when it urges that if an international agency is to be formed at all this should be done before national activities have established awkward precedents. Plainly it is undismayed by the slow start there has been on ocean mining.

\section{Unlucky Strike Again}

Mr Robert L. Strickman, the inventor of a new type of cigarette filter, announced last week his intention of robbing Columbia University of the privilege of developing the filter. The university, to which most of the rights in the filter were assigned, seems likely to dispute this decision and an acrimonious battle through the courts may be in the offing.

Mr Strickman claims that his filter is much more effective than other types both in removing tar and nicotine and in allowing the taste of the tobacco to come through. Wishing to have the filter tested, developed and licensed by a non-profit institution, Mr Strickman offered the rights to Columbia University. In July of last year, Columbia conducted a press conference, the timing and manner of which were widely criticized, to announce its acceptance of $\mathrm{Mr}$ Strickman's offer (Nature, 215, 339; 1967). The university was at that time about to launch a campaign for raising funds of $\$ 200$ million, and the potential income from licensing the filter was undoubtedly a principal factor in its decision. Critics, however, questioned the propriety of an academic institution making money in this way, and pointed out the risk the university took in creating the impression that it condoned or thought innocuous the smoking of cigarettes.

The advisability of its decision apart, Columbia is clearly determined to put the filter through the most. stringent tests it can devise. Here lies the point of disagreement with Mr Strickman, who considers that enough testing has been donc and that Columbia should have already begun licensing the filter to cigarette manufacturers. Although $\mathrm{Mr}$ Strickman is pressing for the return of his rights, he still wishes Columbia to share in the profits from the sale of the filter. The question now is whether Columbia will be able to accept even that truncated connexion with the filter.

\section{Underdeveloped Trade}

The Overseas Development Institute has ventured into a new field with its guide to The Less Developed Countries in World Trade (ODI, 30s.), written by Michael Zammit Cutajar and Alison Franks and published this week. The institute has studied the twoway process of trade for the first time, having previously concentrated on the one-directional flow of official aid and private investment to less developed countries. The trading problems of the less developed countries were examined in detail at the three month United Nations Conference on Trade and Development (UNCTAD) in 1964, and a second UNCTAD conference on the subject is to begin in New Delhi on February 1. The institute, an independent nongovernment body which promotes wide development overseas, hopes that the study will provide background information on the trading problems of the underdeveloped countries which form the majority of UNCTAD. The UNCTAD secretariat has co-operated in the compiling of the guide, although the idea for it came from members of the institute.

Before giving world trade figures and details of the exports of less developed countries, the guide puts forward the fundamentals of economic theory to explain the need for trade. Development cannot be achieved efficiently by either trade or aid alone, and situations are described in which each is most appropriate.

In the 12 years to 1965 , world trade has increased by 135 per cent, but during that time the share of the less developed countries has fallen by over 7 per cent, to less than 20 per cent of the total. When exports are divided into two groups - primary commodities and manufactures-the less developed countries are found to be dependent on the first group, which accounts for 86 per cent of their export earnings. Developed and less developed countries each export about 42 per cent of the world total of primary products, but when it comes to manufactures the development gap is clearly seen. Developed countries export 80 per cent of the world total, while the share of the less developed countries stands at 6 per cent. The guide discusses 